\title{
Transfusion regimens in thalassemia intermedia
}

\author{
Z. Karakas \\ Professor of Pediatrics, Istanbul University, Istanbul School of Medicine, Department of \\ Pediatrics, Division of Hematology/Oncology, Thalassemia Unit, Istanbul, Turkey
}

\begin{abstract}
Thalassemia intermedia (TI) is a heterogeneous disease, in terms of both clinical manifestations and underlying molecular defects. Some TI patients are asymptomatic until adult life, whereas others are symptomatic from early childhood. In contrast with patients with Thalassemia major (TM), the severity of anemia is less and the patients do not require transfusions during at least the first few years of life. Many patients with TI, especially older ones, have been exposed to the multiple long-term effects of chronic anemia and tissue hypoxia and their compensatory reactions, including enhanced erythropoiesis and increased iron absorption. Bone marrow expansion and extramedullary hematopoiesis lead to bone deformities and liver and spleen enlargement. Therapeutic strategies in TI are not clear and different criteria are used to decide the initiation of transfusion and chelation therapy, modulation of fetal hemoglobin production, and hematopoietic stem cell transplantation on an individual basis. The clinical picture of well-treated TM patients with regular transfusionchelation therapy is better from TI patients who have not received adequate transfusion therapy. There is a significant role of early blood transfusion to prevent and treat complications commonly associated with TI, such as extramedullary erythropoiesis and bone deformities, autoimmune hemolytic anemia, leg ulcers, gallstones, pseudoxantoma elasticum, hyperuricosuria, gout and pulmonary hypertension, which are rarely seen in thalassemia major. Nowadays, indications of transfusion in patients with TI are chronic anemia ( $\mathrm{Hb}<7 \mathrm{~g} / \mathrm{dL}$ ), bone deformities, growth failure, extramedullary erythropoiesis, heart failure, pregnancy and preparation for surgical procedures.

Conclusion: Adequate (regular or tailored) transfusion therapy is an
\end{abstract}

Correspondence: Z. Karakas, Professor of Pediatrics, Istanbul University, Istanbul School of Medicine, Department of Pediatrics, Division of Hematology/0ncology, Thalassemia Unit, Istanbul, Turkey.

E-mail: zkarakas@istanbul.edu.tr

Key words: thalassemia intermedia, transfusion.

(C) Copyright Z. Karakas , 2011

Licensee PAGEPress, Italy

Thalassemia Reports 2011; 1(s2):e14

doi:10.4081/thal.2011.s2.e14

This article is distributed under the terms of the Creative Commons Attribution Noncommercial License (by-nc 3.0) which permits any noncommercial use, distribution, and reproduction in any medium, provided the original author(s) and source are credited.

Parts of this work were presented at the "12th International Conference on Thalassemia and Hemoglobinopathies", Antalya (Turkey), 11-14 May 2011. important treatment modality for increasing the quality of life in patients with thalassemia intermedia during childhood.

\section{Introduction}

Thalassemia intermedia was first described in 1955 by RiettiGreppi-Micheli as too hematologically severe to be called minor, but too mild to be called major.

The severity of clinical features is greatly variable, and depends primarily on the underlying molecular defects such as genotype/phenotype correlation.

Three common mechanisms for the pathophysiology of TI are the inheritance of mild $\beta$-thalassemia alleles, co-inheritance of $\alpha$-globin gene mutations and the inheritance of genetic determinants causing high level production of $\mathrm{HbF}$.

Clinical picture of TI includes chronic anemia, ineffective erythropoiesis and iron overload. Chronic anemia leads to splenomegaly and growth failure, whereas ineffective erythropoiesis leads to skeletal deformities, osteopenia and hepatosplenomegaly. ${ }^{1-3}$

Non-transfusional iron overload in the liver and less so in the heart, develops due to increased gastrointestinal iron absorption. ${ }^{4}$

Patients with thalassemia intermedia have a poor appearance and quality of life compared with thalassemia major. Complications occur particularly later in life. They are less common in adequately transfused patients. It is possible that in the future, an adequate transfusion program will become a more common option for management and prevention of late complications.

The difference between thalassemia major and intermedia treatment is mainly regular transfusion. Thalassemia major is a lifelong transfusion-dependent disease. On the other hand, TI is a heterogeneous disease; some are asymptomatic and others are transfusion dependent. Currently no clear guidelines are available on transfusion regimens in TI. ${ }^{1-3}$

There are some questions waiting to be answered: i) Is transfusion therapy required? ii) Is transfusion therapy a routine treatment approach for patients with thalassaemia intermedia? iii) What are the risks/benefits of transfusion therapy? iv) Which regimen of transfusion therapy should be used? (tailored or regular).

\section{Patients and Methods}

Twenty-one patients with thalassemia intermedia were evaluated retrospectively. Patients aged between 10 and 53, have been followed at Istanbul University School of Medicine, Pediatric and Adult Hematology/Oncology Thalassaemia Unit.

Patients were diagnosed between the age of 2 and 14 years. Seven of them were younger, fourteen of them were older than 18 years old (Table 1). 


\section{Results}

Amount of transfusion were greatly variable in patients with TI. Three patients received more than 50 transfusions, whereas four of them had no transfusion (Table 2). The rate of gallstones and the spleen condition in patients with non-transfusion dependent TI are shown in Table 3.

Types of complications of Thalassemia Intermedia were related to age. Autoimmune hemolytic anemia, thalassemic physical appearance and hypersplenism were seen under the age of 10, during childhood. Many complications such as endocrinopathies and heart disease related with iron overload, extramedullary erythropoiesis, cholelithiasis, thromboembolism and leg ulcers developed between 10-50 years of age; pseudoxanthoma elasticum and pulmonary hypertension occurred after 50 years of age during adulthood. Complications in our patients with non-transfusion dependent TI are shown in Table 4.

Long term complications of TI may be severe and irreversible. Early treatment with blood transfusion may prevent the complications. Relationship between the amount of transfusions and complications and the types of mutations are shown in Table 5.

We evaluated the relationship between transfusions and $\mathrm{Hb}$ level at Table 6 .

Transfusion indications in our patients with non-transfusion dependent thalassemia intermedia are shown in Table 7.

\section{Discussion}

There is no adequate clinical definition of TI. TI has a broad clinical spectrum, and different transfusion regimens are used according to these conditions. There are three transfusion therapy options in patients with TI: no transfusions, intermittent or tailored transfusions and regular transfusions, although they have some risks and benefits (Table 8).

Table1. Demographic features of patients with non-transfusion dependent thalassemia intermedia.

\begin{tabular}{lc} 
Patients & 21 \\
No. & $10-53$ \\
Age & $2-14$ \\
\hline Age at diagnosis & 7 \\
$<18$ y & 14 \\
$>18$ y & 12 \\
Female & 9 \\
\hline Male &
\end{tabular}

Table 2. Amount of transfusion in patients with non-transfusion dependent thalassemia intermedia.

\begin{tabular}{lcc} 
Transfusion number & n. & Patient's Age \\
None & 4 & $10,12,25,44$ \\
$<10$ & 3 & $23,28,33$ \\
\hline $10-20$ & 6 & $14,15,19,24,32,40$ \\
\hline $20-30$ & 3 & $12,15,35$ \\
$30-50$ & 2 & 36,38 \\
\hline$>50$ & 3 & $16,51,53$ \\
Total & 21 & $10-53$ \\
\hline
\end{tabular}

i) If $\mathrm{Hb}$ level persists between $9-10 \mathrm{~g} / \mathrm{dL}$ with splenomegaly, it is called mild TI. They don't require transfusion. ii) If $\mathrm{Hb}$ levels are in the 5-6 g/dL range, and the presentation is relatively late, with growth failure and gross skeletal deformities, it is severe TI. These children should be transfused to avoid complications (treated like TM). iii) If $\mathrm{Hb}$ values are between 6 and $9 \mathrm{~g} / \mathrm{dL}$ and growth and development are reasonably well, it is named as moderate TI and in these patients, the decision to transfuse is challenging. There is no routine treatment approach which provides significant benefits. Transfusions may be required if complications develop. Transfusions may also become necessary with advancing age, during infection and pregnancy, and when hypersplenism develops. Diagnosis can be made after an observation and often requires revision.

Thalassemia phenotypes and transfusion requirements are shown in Figure 1.

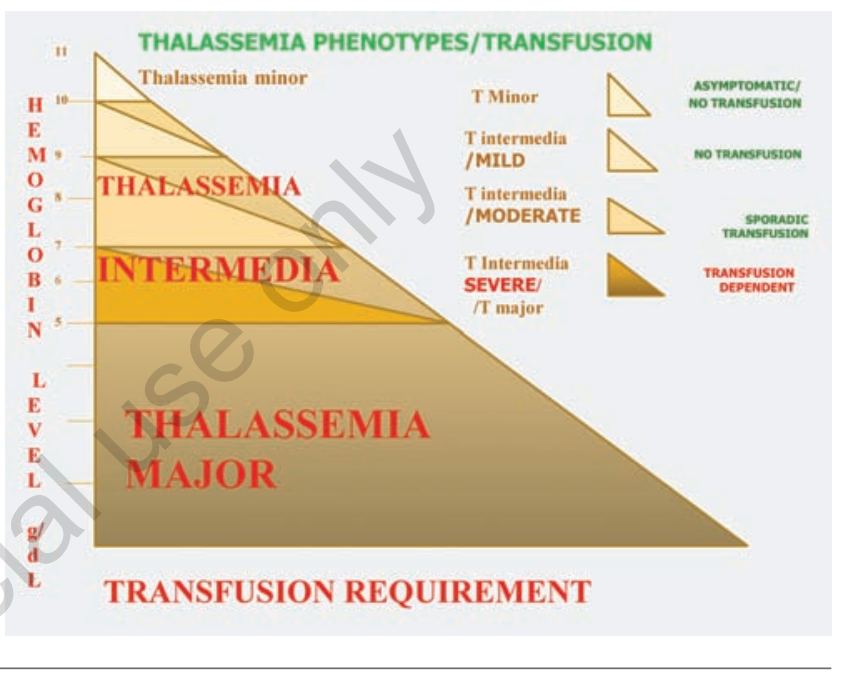

Figure 1.

Table 3. Gallstones and spleen in patients with non-transfusion dependent TI.

\begin{tabular}{lcc} 
& $\mathrm{n}$. & $\%$ \\
Splenomegaly & 11 & 52 \\
Massive splenomegaly & 3 & 14 \\
\hline Splenectomy & 7 & 33 \\
Gallstones & 6 & 27 \\
\hline Cholecystectomy & 4 & 18 \\
\hline
\end{tabular}

Table 4. Complications in patients with non-transfusion dependent TI.

\begin{tabular}{lcc} 
Complications & n. & $\%$ \\
Osteoporosis & 11 & 52 \\
Growth failure (<3. percentile, childhood) & $4 / 7$ & 57 \\
\hline Short stature(adult) & $2 / 14$ & 14 \\
Extramedullary hematopoiesis (spinal cord) & 3 & 14 \\
\hline Bone pain (severe) & 3 & 14 \\
Gout, infection & 2 & 10 \\
Syncope, hypothyroidism, epistaxis, hair loss, & & \\
pins and needles & 1 & 5 \\
Thrombosis & 1 & 5 \\
\hline
\end{tabular}


Answers to the following questions are not clear yet: i) Do transfusions prevent complications? ii) Are the complications increased by transfusions? iii) When the patients with non-transfusion dependent TI have to receive transfusion?

We have shown that decision of transfusion is not difficult in mild or severe forms of thalassemia intermedia. An individual treatment modality is required in the moderate form of the disease.

Today, the approach of transfusion therapy in TI does not seem to be appropriate: i) Avoiding early blood transfusions and concomittant requirement for chelation therapy. ii) Reserving the transfusion until later in the course of the disease, when complications manifest.

The decision to initiate transfusion therapy in TI should be based not only on the $\mathrm{Hb}$ level but also on signs and symptoms of anemia, patient's condition (particularly with respect to activity, failure of growth and development), and early appearance of skeletal changes or other disease complications. Indications to transfuse regularly in thalassemia intermedia are chronic anemia $(\mathrm{Hb}<7 \mathrm{~g} / \mathrm{dL})$, bone deformities, growth failure, extramedullary erythropoiesis, heart failure and pregnancy. 1

Table 5. Relationship between transfusion number and complications.

\begin{tabular}{|c|c|c|}
\hline Transfusion & Mutations & Complications \\
\hline $\begin{array}{l}\text { None } \\
(n: 4)\end{array}$ & $\begin{array}{l}\text { IVS II-I/IVS 1-6 } \\
\text { CD } 8 / \alpha \text { triplication } \\
2 \mathrm{NA}\end{array}$ & $\begin{array}{l}4 \text { splenomegaly } \\
1 \text { osteoporosis }\end{array}$ \\
\hline $\begin{array}{l}<10 \\
(n: 3)\end{array}$ & $\begin{array}{l}-30 /-30 \\
2 \mathrm{NA}\end{array}$ & $\begin{array}{l}3 \text { splenomegaly (1 massive) } \\
1 \text { osteoporosis } \\
1 \text { splenectomy } \\
1 \text { cholecystectomy }\end{array}$ \\
\hline $\begin{array}{l}10-20 \\
(\mathrm{n}: 6)\end{array}$ & $\begin{array}{l}2 \text { IVS 1-6/IVS 1-6 } \\
\text { CD 39/IVS I-6 } \\
\text { CD 39/CD 39 } \\
-30 /-30 \\
\text { NA }\end{array}$ & $\begin{array}{l}2 \text { masssive splenomegaly, } 4 \text { gallstones, } \\
3 \text { osteoporosis, } 3 \text { splenectomy, } \\
2 \text { growth failure, } 2 \text { EMH, } \\
9 \text { others }\end{array}$ \\
\hline $\begin{array}{l}20-30 \\
(\mathrm{n}: 3)\end{array}$ & $\begin{array}{l}\text { IVS II-I/IVS II-I } \\
\text { NA (n:2) }\end{array}$ & $\begin{array}{l}1 \text { joint ache, } 2 \text { splenectomy, } \\
1 \text { splenomegaly, } 1 \text { infection, } \\
1 \text { gallstone, } 1 \text { osteoporosis, } \\
1 \text { splenectomy, } 1 \text { growth failure, } \\
3 \text { others }\end{array}$ \\
\hline $\begin{array}{l}30-50 \\
(\mathrm{n}: 2) \\
>50 \\
(\mathrm{n}: 3)\end{array}$ & $\begin{array}{l}\text { IVS I-6/Codon } 8 \\
\text { NA } \\
-30 /-30 \\
2 \text { NA }\end{array}$ & $\begin{array}{l}2 \text { splenomegaly, } 1 \text { cholecystectomy, } \\
1 \text { bone deformity, } 1 \text { gallstone } \\
2 \text { splenomegaly, } 1 \text { splenectomy, } \\
1 \text { cholecystectomy, } 2 \text { osteoporosis, } \\
1 \text { short stature, } 1 \text { EMH, } \\
1 \text { hypothyroidism, } 1 \text { amenorrhea, } \\
1 \text { joint pain }\end{array}$ \\
\hline
\end{tabular}

Table 6. Relationship between transfusions and $\mathrm{Hb}$ level

\begin{tabular}{lcccc} 
Transfusion & $5-7$ & $7-9$ & $g-10$ & $>10$ \\
count & $g / d$ L & $g / d L$ & $g / d L$ & $g / d L$ \\
None & - & - & 2 & 2 \\
$<10$ & - & 2 & 1 & - \\
\hline $10-20$ & 1 & 4 & 1 & - \\
$20-30$ & 1 & 1 & 1 & - \\
\hline $30-50$ & - & 2 & - & - \\
$>50$ & - & 2 & 1 & 2 \\
\hline Total & 2 & 11 & 6 & \\
\hline
\end{tabular}

Evaluation of the role of transfusion therapy in the management of TI has been limited, in contrast with TM. In the OPTIMAL CARE study, patients who were placed on transfusion regimens (intermittent or regular) suffered fewer complications relevant to chronic anemia, ineffective erythropoiesis, and hemolysis (mainly extramedullar hematopoiesis, pulmonary hypertension (PHT), and thrombosis), but suffered while a higher rate of iron overload related endochrinopathy.${ }^{7}$ Observational studies have also confirmed that transfused TI patients suffer fewer thromboembolic events, PHT, and silent brain infarcts as compared to transfusion-naive patients. Blood transfusion in patients with TI will require closer monitoring and should be individually tailored to meet the patient's needs. Alloimmunization is a relatively common observation in TI, and the risk is decreased if transfusion therapy is initiated before the age of 12 months. ${ }^{1}$

Patients with thalassemia intermedia may benefit from an individually tailored transfusion regimen, compared with the regular transfusion regimens implemented in thalassemia major, to help prevent transfusion dependency.

Current indications for transfusion therapy in $\mathrm{TI}$ are a $\mathrm{Hb}$ level of

Table 7. Transfusion indications in patients with non-transfusion dependent TI.

\begin{tabular}{lc} 
Indication of transfusions & Patients $\mathrm{n}$. \\
Infection & 13 \\
Hypersplenism & 9 \\
\hline Surgery & 9 \\
Growth failure & 8 \\
\hline Extramedullary hematopoiesis & 3 \\
Pregnancy & 2 \\
\hline
\end{tabular}

Table 8. Risk and benefits of different transfusion regimens.

\begin{tabular}{lll}
\hline REGULAR & REGULAR & TAILORED \\
TRANSFUSION & TRANSFUSION & $\begin{array}{l}\text { TRANSFUSION } \\
\text { BNDICANIONS }\end{array}$ \\
$\begin{array}{l}\text { Bone deformities } \\
\text { Growth failure }\end{array}$ & $\begin{array}{l}\text { Transfusion dependency } \\
\text { Transfusion transmitted } \\
\text { infections }\end{array}$ & $\begin{array}{l}\text { CHILDHOOD } \\
\text { Bone deformities }\end{array}$ \\
\hline $\begin{array}{l}\text { Autoimmune hemolytic } \\
\text { anemia }\end{array}$ & $\begin{array}{l}\text { Transfusion reactions } \\
\begin{array}{l}\text { Extramedullary } \\
\text { erythropoiesis }\end{array}\end{array}$ & Growth failure \\
\hline $\begin{array}{l}\text { Hypersplenism } \\
\text { Hyperuricosuria and } \\
\text { Gout }\end{array}$ & Oron overload & School performance \\
\hline $\begin{array}{l}\text { Pseudoxantoma } \\
\text { elasticum }\end{array}$ & Growth failure & ADULTHOOD \\
Thromboembolism & Delayed puberty & Pregnancy \\
\hline $\begin{array}{l}\text { Pulmonary } \\
\text { hypertension }\end{array}$ & Diabetes mellitus & ALL \\
$\begin{array}{l}\text { Heart disease from } \\
\text { hypoxia }\end{array}$ & Hypothyroidism & Hypersplenism \\
\hline $\begin{array}{l}\text { Increased iron } \\
\text { absorption } \\
\text { Cholelithiasis }\end{array}$ & Hypoparathyroidism & Symptomatic anemia \\
\hline $\begin{array}{l}\text { Infections } \\
\text { Leg ulcers }\end{array}$ & Cost (Need of chelation) & BENEFITS \\
\hline
\end{tabular}


less than $5 \mathrm{~g} / \mathrm{dL}$, declining $\mathrm{Hb}$ level in parallel with a profound enlargement of the spleen, growth failure (height is more specific than weight for growth), poor performance at school, diminished exercise tolerance, failure of secondary sexual development in parallel with bone age, severe bony changes, pregnancy, or the development of infection and other complications, eg. heart failure, pulmonary hypertension, thromboembolic disease, leg ulcers and priapism. However, until acceptable evidence-based guidelines are available, individualized treatment should be recommended. ${ }^{2}$

\section{References}

1. Blood Transfusion Therapy in Thalassaemia Major in Guidelines for the clinical management of the thalassemia, Thalassemia International Federation, 2 th revised edition, 2008:20-33.

2. Taher AT, Musallam KM, Cappellini MD and Weatherall DJ. Optimal management of $\beta$ thalassaemia intermedia British Journal of Haematology, 2011;152:512-523.

3. Borgna-Pignatti C, Marsella M, and Zanforlin N. The natural history of thalassemia intermedia. Ann. N.Y. Acad. Sci. 2010;1202: 214 220.

4. Taher A, Hershko C, Cappellini MD. Iron overload in thalassaemia intermedia: reassessment of iron chelation strategies. British Journal of Haematology, 2009;147:634-640.

5. Taher AT, Musallam KM, Karimi M, et al. Overview on practices in thalassemia intermedia management aiming for lowering complication rates across a region of endemicity: the OPTIMAL CARE study. Blood, 2010;115:1886-1892.

6. Taher AT, Musallam KM, El-Beshlawy A, et al. Age related complications in treatment-naive patients with thalassaemia intermedia. British Journal of Haematology, 2010;150:486-489.

7. Taher A, Ismaeel H, Mehio G, et al. (2006b) Prevalence of thromboembolic events among 8,860 patients with thalassaemia major and intermedia in the Mediterranean area and Iran. Thrombosis \& Haemostasis, 2006;96:488-491. 